\title{
A Novel Localized Amyloidosis Associated with Lactoferrin in the Cornea
}

\author{
Yukio Ando, Masaaki Nakamura, Hirofumi Kai, Shoichi Katsuragi, \\ Hisayasu Terazaki, Takayuki Nozawa, Toshiya Okuda, Shogo Misumi, \\ Noriko Matsunaga, Kanako Hata, Takahiro Tajiri, Shozo Shoji, Taro Yamashita, \\ Katsuki Haraoka, Konen Obayashi, Koki Matsumoto, Masayuki Ando, and \\ Makoto Uchino
}

Department of Laboratory Medicine (YA, NM, KH, TT), Department of Neurology (MN, TY, KO, MU), First Department of Internal Medicine (HT, KH, MA), and Department of Ophthalmology (TO, KM), Kumamoto University School of Medicine; Department of Pharmacological Sciences (HK) and Department of Biochemistry (SM, SS), Faculty of Pharmaceutical Sciences, Kumamoto University, Oe-honmachi, Kumamoto; Department of Psychiatry (SK), Kikuchi Ryoyo-sho Hospital, Oaza-Fukuhara, Koshi-machi, Kikuchi-gun; and Department of Pathology (TN), Kanazawa Medical University Hospital, Daigaku, Uchinada-machi, Kahoku-gun, Ishikawa, Japan

SUMMARY: We report a novel localized amyloidosis associated with lactoferrin. To elucidate the precursor protein of corneal amyloidosis associated with trichiasis, we analyzed amyloid deposits from three patients by histopathology and biochemistry. Amyloid deposits showed immunoreactivity, confirmed by electron microscopy, for only anti-human lactoferrin antibody. Electrophoresis of amyloid fibrils revealed lactoferrin with and without sugar chains; N-terminal sequence analysis revealed full-length lactoferrin and a truncated tripeptide of N-terminal amino acids, Gly-Arg-Arg. Carboxymethylated wild-type lactoferrin formed amyloid fibrils in vitro. Lactoferrin gene analysis in the three patients revealed a Glu561Asp mutation in all of the patients and a compound heterozygote of Ala11Thr and Glu561Asp mutations in one patient. A heterozygotic Glu561Asp mutation appeared in $44.8 \%$ of healthy Japanese volunteers, suggesting that the mutation may not be an essential mutation for amyloid formation $(p=0.104)$. Results thus suggest that lactoferrin is this precursor protein. (Lab Invest 2002, 82:757-765).

$A$ myloidosis is a disorder of protein metabolism in which normally soluble autologous proteins are deposited in tissues as abnormal insoluble fibrils that cause structural and functional disruptions (Benson, 1995; Kelly, 1998; Tan and Pepys, 1994). They are usually characterized by an extracellular deposition of amyloid in various tissues and are classified as localized or systemic amyloidoses (Benson, 1995; Benson and Uemichi, 1996; Tan and Pepys, 1994). Progress in molecular genetics and biochemical methodologies has led to identification of various types of amyloidoses and their amyloidogenic precursor proteins (Benson, 1995; Benson and Uemichi, 1996; Kelly, 1998; Tan and Pepys, 1994). However, the mechanism of formation of amyloid fibrils in tissues remains to be

\section{DOI: 10.1097/01.LAB.0000017170.26718.89}

Received January 29, 2002.

This work was supported by grants from the Amyloidosis Research Committee, the Pathogenesis and Therapy of Hereditary Neuropathy Research Committee, Surveys and Research on Specific Disease of the Ministry of Health, and Welfare of Japan.

Address reprint requests to: Dr. Yukio Ando, Department of Laboratory Medicine, Kumamoto University School of Medicine, 1-1-1 Honjo, Kumamoto 860-0811, Japan. E-mail:yukio@kaiju.medic.kumamoto-u.ac.jp elucidated for all types of amyloidosis, although evidence has been provided for several possible hypotheses (Ando et al, 1997b; Colon et al, 1996; Goldsteins et al, 1999; Miyata et al, 1996; Pepys et al, 1994; Quintas et al, 1997; Tennent et al, 1995).

Ocular tissues are one type of tissue in which several different types of amyloid precursor proteins deposit as amyloid fibrils (Lee et al, 2000; Nelson et al, 1999). Most of these amyloid precursor proteins have been identified for systemic amyloidoses in ocular tissues (Ando et al, 1997a; Campos et al, 1980; Ratnakar and Mohan, 1976; Rodrigues and Zimmerman, 1971; Sandgren, 1995). At least four varieties of lattice corneal dystrophy and gelatinous drop-like corneal dystrophy are classified as hereditary corneal amyloidosis (Gorevic et al, 1991; Klintworth et al, 1997; Nishida et al, 1999). The precursor protein of amyloid fibrils in the former disorder is mutant gelsolin, which induces systemic disorders as well as corneal amyloidosis; in the latter, the precursor protein of the amyloid remains unknown. Although lactoferrin was isolated from corneas with gelatinous drop-like corneal dystrophy (familial subepithelial corneal amyloidosis) (Klintworth et al, 1997), the lactoferrin gene mutation is not associated with this hereditary disease (Klintworth et al, 1997; Tsujikawa et al, 1999) and 
suggests that lactoferrin is only a colocalizing protein of the amyloid deposits.

Secondary corneal amyloidosis has been reported in cases of keratoconus, trachoma, phlyctenular keratitis, bullous keratopathy, interstitial keratitis, syphilis, and trichiasis (Aso and Wakakura, 2000; Dutt et al, 1992; Hill et al, 1990; Kigasawa et al, 1996; Watts and Frank, 1989). Although amyloid deposits have been identified with possible colocalization of several proteins, the precursor protein of the amyloid deposits remains unidentified (Janssen et al, 1985; Kigasawa et al, 1996). Thus, the pathogenesis of secondary corneal amyloidosis has not yet been elucidated.

We studied three patients with a novel corneal amyloidosis associated with trichiasis. Of the few proteins tested by immunohistochemistry, only lactoferrin and serum amyloid $\mathrm{P}$ component (SAP) were colocalized; other possible antibodies for amyloid precursor proteins did not react with the amyloid deposits. Thus, we examined amyloidogeneity of lactoferrin in vitro by biochemical and electron microscopic methods. To analyze a possible mutation in the lactoferrin gene, DNA of one patient was analyzed by molecular genetic methods.

\section{Results}

\section{Histochemical Analyses of Biopsied Corneal Samples}

Studies of biopsied corneal samples with Congo red stain revealed positive staining just under the corneal epithelial cells that extended into the stroma (Fig. 1, $a$ and b). Neither vascularization nor infiltration of inflammatory cells was observed. Immunoreactivity of anti-human-lactoferrin antibodies was
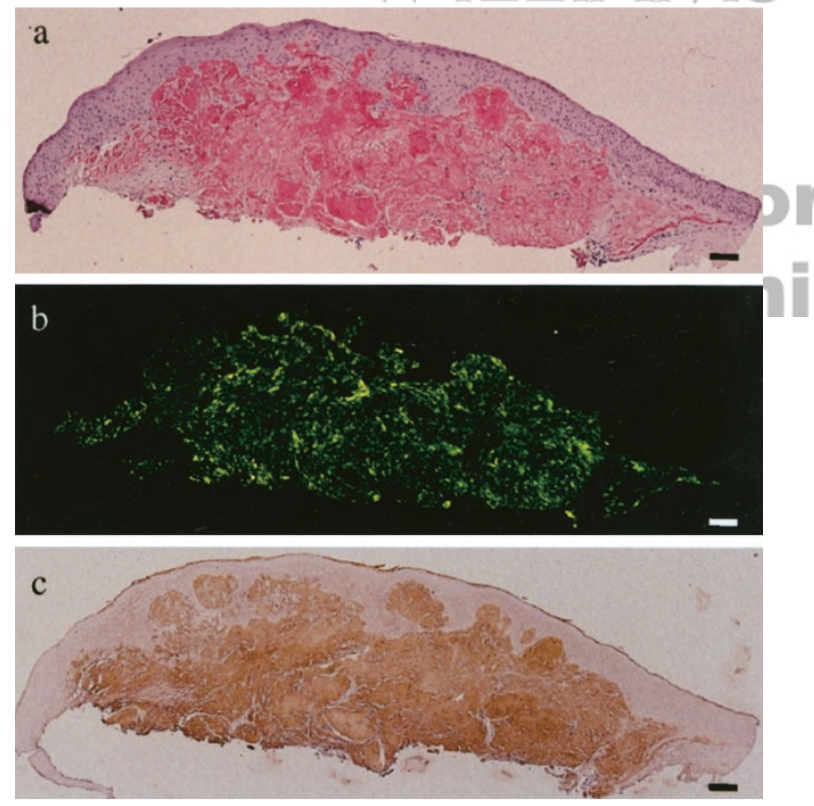

Figure 1.

Congo red and immunohistochemical staining of specimens from a 30-yearold male patient with corneal amyloidosis. a, Congo red stain. b, Congo red stain examined under polarized light. c, Anti-lactoferrin antibody immunostain. Original magnification, $\times 400$. Length of the bars, $25 \mu \mathrm{m}$. recognized in all tissues with positive Congo red staining (Fig. 1c). In and around the amyloid deposits, no inflammatory cells were recognized. Other antibodies, such as polyclonal anti-human transthyretin, anti-human kappa, lambda light chain, antihuman lysozyme antibodies, and monoclonal antihuman-AA and anti-human-keratin antibodies, showed no immunoreactivity for the amyloid deposits. Specificity controls were obtained by preincubating the anti-human-lactoferrin antibody with lactoferrin (1 to $10 \mu \mathrm{g} / \mathrm{ml}$ ) (El-Salhy and Suhr, 1996). Replacing the primary antiserum with albumin or nonimmune serum eliminated the staining.

\section{Electron Microscopic Analyses}

Electron microscopic analyses revealed that amyloid deposits in the tissues were seen as gently curved, nonbranching fibrils 12 to $14 \mathrm{~nm}$ wide (Fig. 2a). They were composed of successive subunits $3 \mathrm{~nm}$ in diameter. After immunolabeling, electron microscopic studies were performed. Gold particles were localized predominantly over amyloid fibrils (Fig. 2b).

\section{SDS-PAGE after Immunoprecipitation}

Immunoprecipitated amyloid fibrils with anti-human lactoferrin antibody of a 30-year-old male patient's sample were found to migrate as two bands in SDSPAGE. By comparison with molecular size markers, sizes of $78.6 \mathrm{kDa}$ for Band $A$ and $81.9 \mathrm{kDa}$ for Band $B$ were obtained (Fig. 3).

\section{N-Terminal Sequence Analysis}

$\mathrm{N}$-terminal amino acid sequence analysis for the sample electrotransferred onto poly(vinylidene fluoride) (PVDF) membrane revealed that both bands were composed of two kinds of isoforms. For Band A, shown in Figure 3, an intact form of lactoferrin and an N-terminal tripeptide (Gly-Arg-Arg), a truncated form of lactoferrin, were confirmed (Table 1), in an approximate proportion of 1:2. Results for Band B were identical to those for Band A.

\section{Amyloid Fibril Synthesis In Vitro}

To examine whether lactoferrin forms amyloid fibrils in vitro, we used the thioflavin $\mathrm{T}$ binding assay with wild-type lactoferrin and carboxymethylated lactoferrin. Wild-type lactoferrin did not induce amyloid formation under any conditions. However, carboxymethylated lactoferrin formed amyloid fibrils in the aging solution (Fig. 4a), and this process was accelerated in PBS (-) buffer, $\mathrm{pH} 7.4$.

\section{Electron Microscopic Analyses of Synthesized Amyloid Fibrils}

Electron microscopy was used to confirm the results of the thioflavin T binding assay. Straight and nonbranching filaments, $9 \mathrm{~nm}$ wide, were observed (Fig. 4b). 
a

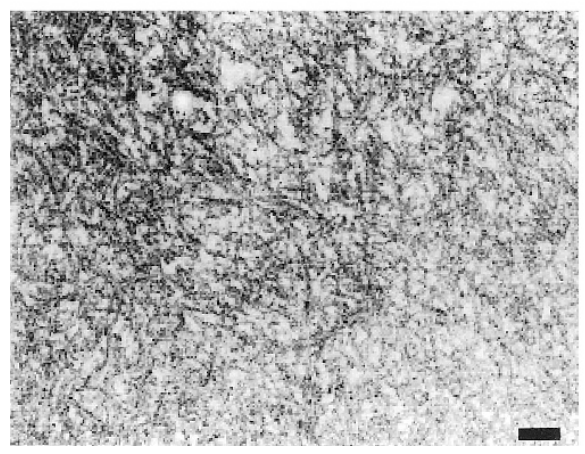

b

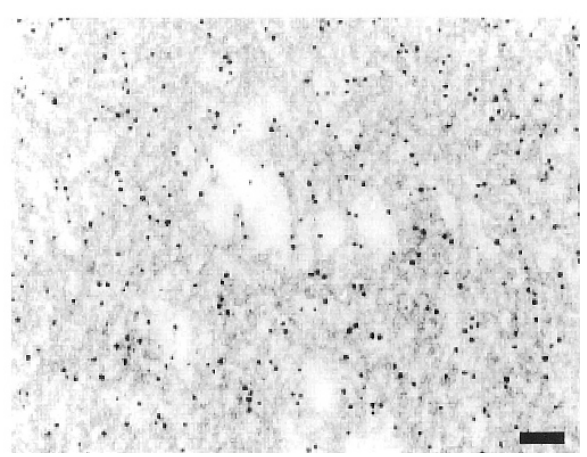

Figure 2.

Electron microscopic analyses of specimens from a 41-year-old female patient with corneal amyloidosis. Electron microscopy with (a) and without (b) immunolabeling. Original magnification: $a, \times 135,000 ; b, \times 70,780$. Length of the bars: $a, 0.07 \mu \mathrm{m} ; b, 0.14 \mu \mathrm{m}$.

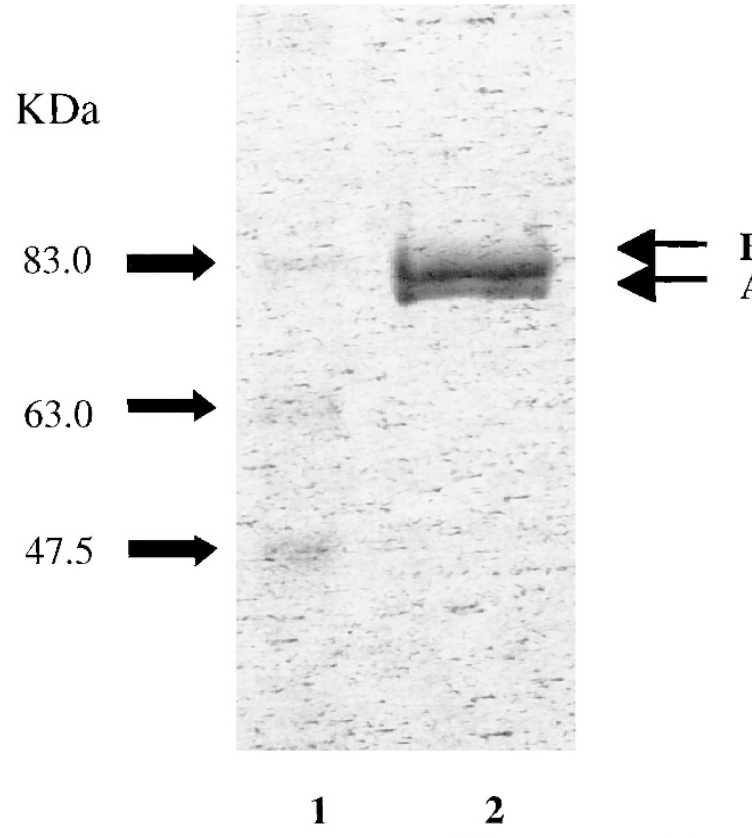

Figure 3.

SDS-PAGE of amyloid fibrils. A sample from a 30 -year-old patient was subjected to SDS-PAGE, with $4 \%$ to $20 \%$ polyacrylamide gel. Lane 1 , molecular size markers; Lane 2, amyloid fibrils. Band A, 78.6 kDa; Band B, 81.9 $\mathrm{kDa}$.

\section{Circular Dichroism (CD) Spectra}

In the far-UV region (200 to $240 \mathrm{~nm}$ ), the CD spectra of wild-type lactoferrin and carboxymethylated lactoferrin in PBS (-) buffer were distinguishable, as shown in Figure 4c. According to the k2d program (Andrade et al, 1993; Merelo et al, 1994), wild-type lactoferrin contained 29\% $\alpha$-helix, 36\% $\beta$-sheet, and 36\% random coil. Carboxymethylated lactoferrin contained $26 \% \alpha$-helix, $17 \% \beta$-sheet, and $58 \%$ random coil: the $\beta$-sheet content decreased but random coil content increased. Carboxymethylated lactoferrin incubated for 2 days at $37^{\circ} \mathrm{C}$ contained 9\% $\alpha$-helix, 35\% $\beta$-sheet, and $55 \%$ random coil, whereas that incubated for 7 days at $37^{\circ} \mathrm{C}$ contained $8 \% \alpha$-helix, $43 \%$ $\beta$-sheet, and $50 \%$ random coil (Fig. 4c). No change in the conformation of wild-type lactoferrin was observed during incubation.

\section{Analyses of the Lactoferrin Gene in a Patient with Corneal Amyloidosis}

B Single-strand conformation polymorphism (SSCP) analyses revealed abnormally migrating bands in exon $2,9,10$, and 15 in a 30-year-old male patient, and exon 15 in the other two patients, respectively. Direct sequencing using exon $2,9,10$, and 15 PCR products from the patient's DNA was performed to identify these mutations or polymorphisms. In exons 9 and 10 , two polymorphisms were detected: a GTC (Val) to GTT (Val) substitution in codon 346 of exon 9 and a GGA (Gly) to GGG (Gly) substitution in codon 398 of exon 10. In exon 2 and 15, two mutations were detected: amino acid substitutions at codon 11 from GCC (Ala) to ACC (Thr) in the 30-year-old male patient and at codon 561 from GAG (Glu) to GAC (Asp) in all three patients. PCR-RFLP analysis, performed to confirm these mutations, revealed digestion bands (61 bp and $146 \mathrm{bp}$, and $158 \mathrm{bp}$ and $28 \mathrm{bp}$ ) in addition to the normal band (207 bp and $186 \mathrm{bp}$ ), indicating that the 30-year-old male patient was a heterozygote with the lactoferrin Ala11Thr and Glu561Asp gene, and that the other two patients were a heterozygote for the lactoferrin Glu561Asp gene (Fig. 5). PCR-RFLP for the parents of the 30-year-old male patient revealed that the father was a heterozygote of Ala11Thr and the mother was a heterozygote of Glu561Asp (Fig. 5), indicating that the male patient was a compound heterozygote for the lactoferrin Ala11Thr and Glu561Asp gene.

The frequency of these mutations in Japanese volunteers was also determined by using PCR-RFLP. The frequency of genotype Ala/Thr $+/+$, Glu/Asp $+/+$, and $\mathrm{Ala} / \mathrm{Thr}+/+$ plus Glu/Asp +/+ was $34.2 \%$, $44.8 \%$, and $15.8 \%$, respectively (Table 2 ).

\section{Discussion}

We have demonstrated here that lactoferrin forms amyloid in the cornea in patients with lactoferrin 
Table 1. N-Terminal Sequence ${ }^{a}$

\begin{tabular}{ccccccccccccccc}
\hline & 1 & 2 & 3 & 4 & 5 & 6 & 7 & 8 & 9 & 10 & 11 & 12 & 13 & 14 \\
\hline$(\mathrm{A})^{b}$ & $\mathrm{G}$ & $\mathrm{R}$ & $\mathrm{R}$ & $\mathrm{R}$ & $\mathrm{R}$ & $\mathrm{S}$ & $\mathrm{V}$ & $\mathrm{Q}$ & $\mathrm{W}$ & $\mathrm{C}$ & $\mathrm{A}$ & $\mathrm{V}$ & $\mathrm{S}$ & $\mathrm{Q}$ \\
$(\mathrm{B})^{c}$ & $\mathrm{G}$ & $\mathrm{R}$ & $\mathrm{R}$ & $\mathrm{R}$ & $\mathrm{R}$ & $\mathrm{S}$ & $\mathrm{V}$ & $\mathrm{Q}$ & $\mathrm{W}$ & & $\mathrm{A}$ & & & \\
$(\mathrm{C})^{d}$ & & & & $\mathrm{R}$ & $\mathrm{R}$ & $\mathrm{S}$ & $\mathrm{V}$ & $\mathrm{Q}$ & $\mathrm{W}$ & & $\mathrm{A}$ & $\mathrm{V}$ & $\mathrm{S}$ & $\mathrm{Q}$ \\
\hline
\end{tabular}

${ }^{a}$ To block the effect of Cys on the sequence analysis, pyridylethylation of Cys residues in the protein was performed (Kao and Chung, 1993). The blanks represent the blocked Cys residues.

${ }^{b} \mathrm{~N}$-terminal sequence of lactoferrin.

${ }^{c}$ Intact lactoferrin.

${ }^{d}$ Truncated tripeptide of N-terminal amino acids, Gly-Arg-Arg

a

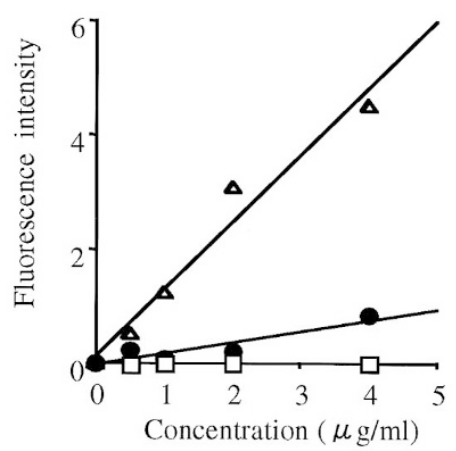

b

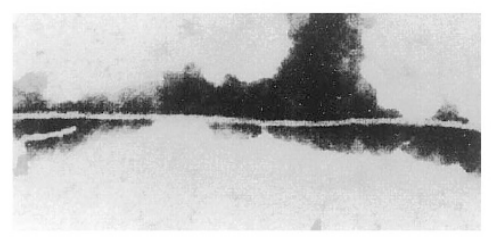

c

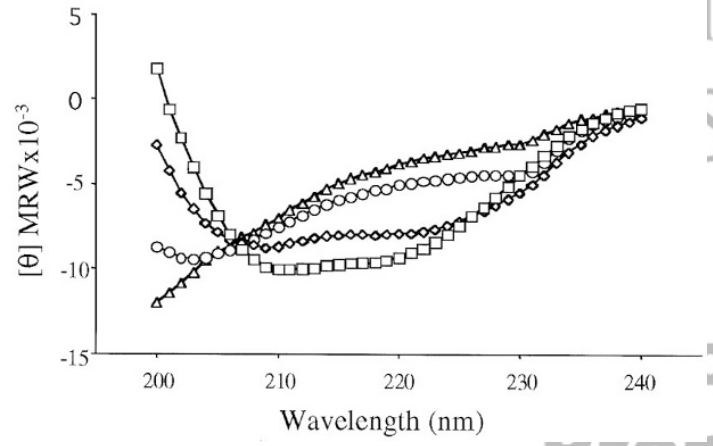

Figure 4.

Evaluation of produced amyloid fibrils. a, Thioflavin $t$ test: $(\bullet)$ carboxymethylated lactoferrin, pH 3.5, Day 6; $(\square)$ wild-type lactoferrin, pH 3.5, Day 6; $(\triangle)$ carboxymethylated lactoferrin, pH 7.4, Day 6, after aging in the buffer, as described in the text. b. Electron microscopy: Original magnification, $\times 225,000$. Length of the bar: $0.04 \mu \mathrm{m}$. c, Circular dichroism analysis: $(\square)$ wild-type lactoferrin; $(\diamond)$ carboxymethylated lactoferrin; $(\circ)$ carboxymethylated lactoferrin Day 2 after aging; and $(\triangle)$ carboxymethylated lactoferrin Day 7 after aging.

mutation. Lactoferrin is an iron-binding glycoprotein found in milk, in exocrine secretions of mammals, and in secondary granules from polymorphonuclear neutrophils (Baker et al, 1998). Among various antibodies tested, lactoferrin and SAP showed colocalization with amyloid deposits. SAP is a well-known colocalizing protein in most amyloidosis. Electron microscopy confirmed the presence of amyloid fibrils, and immunoreactivity of anti-lactoferrin antibody was observed in a

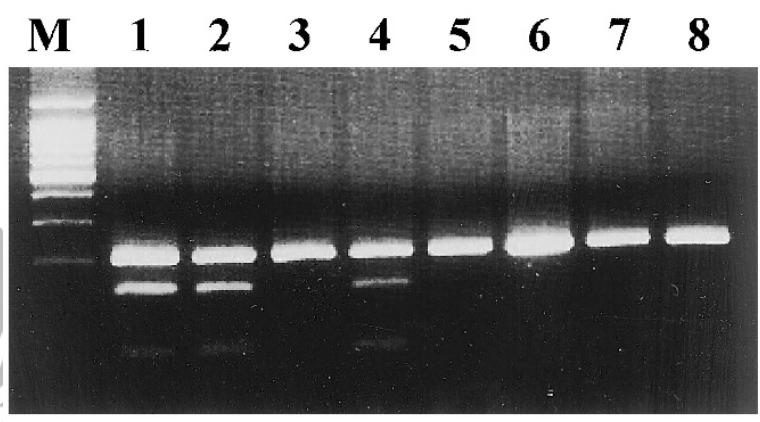

b

\section{$\begin{array}{lllllllll}M & 1 & 2 & 3 & 4 & 5 & 6 & 7 & 8\end{array}$}

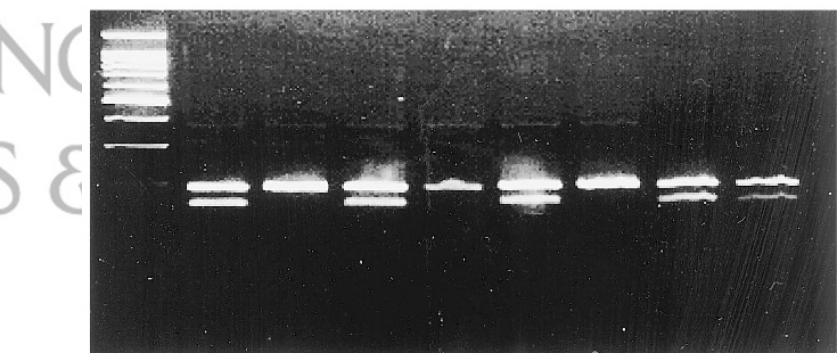

Figure 5.

Detection of the lactoferrin Ala11Thr and Glu561Asp gene by PCR-RFLP. PCR-RFLP analyses for (a) Ala11Thr and (b) Glu561Asp using ApaLI and Aatll, respectively, as described in the text. $M$ : 100 bp DNA ladder size marker; Lane 1: the proband (30-year-old man); 2: father; 3 : mother; 4 : the younger brother; 5: the younger sister; 6 : healthy controls; 7 : other patient (41-year-old woman); and 8: other patient (67-year-old woman).

immunolabeled material. Because most of the excised tissue was covered with amyloid, it was not difficult to extract amyloid fibrils. SDS-PAGE and N-terminal sequence analysis revealed that amyloid fibrils consisted of full-length lactoferrin and truncated lactoferrin with and without sugar chains. Four different isoforms of lactoferrin were found in the amyloid fibrils.

Because no lactoferrin is detected in plasma, and because no tissues except for lacrimal glands in and around the ocular tissues produce lactoferrin, the origin of lactoferrin formed in the amyloid fibrils may be tears from the lacrimal glands. Another possible origin of lactoferrin is polymorphonuclear leukocytes that migrate to the cornea, although we detected no 
Table 2. Frequency of Lactoferrin Genotypes in Japanese Volunteers

\begin{tabular}{|c|c|c|c|}
\hline $\begin{array}{l}\text { Codon } 11 \text { Ala } \\
\text { (GCC)/Thr (ACC) }\end{array}$ & $\begin{array}{l}\text { Codon } 561 \text { Glu } \\
(\text { GAG)/Asp (GAC) }\end{array}$ & Number & $\begin{array}{c}\text { Frequency } \\
(\%)\end{array}$ \\
\hline$+1-$ & $+1-$ & 4 & 10.5 \\
\hline$+1-$ & $+1+$ & 8 & 21.1 \\
\hline$+1-$ & $-1+$ & 4 & 10.5 \\
\hline$+/+$ & $+1-$ & 7 & 18.4 \\
\hline$+1+$ & $+1+$ & 6 & 15.8 \\
\hline$+1+$ & $-1+$ & 0 & 0 \\
\hline$-1+$ & $+1-$ & 6 & 15.8 \\
\hline$-1+$ & $+1+$ & 3 & 7.9 \\
\hline$-1+$ & $-1+$ & 0 & 0 \\
\hline
\end{tabular}

+ , carrier of the gene; - , noncarrier of the gene.

The frequency of the healthy volunteers carrying both Ala11Thr and Glu561Asp was $23.7 \%(15.8+0+7.9+0=23.7)$.

inflammatory cells in the biopsied materials. During repeated stimulation of the cornea by trichiasis, there is a slight possibility that lactoferrin may originate from cells that migrate to the lesions.

We examined the possibility of amyloid fibril formation by wild-type lactoferrin in vitro. Wild-type lactoferrin could not form amyloid fibrils, as shown in Figure 4, although modified lactoferrin could. This suggests that lactoferrin, like other amyloid precursor proteins (Kelly, 1998; Serpell et al, 1997; Sunde and Blake, 1997), cannot form amyloid fibrils without conformational changes. In fact, CD analysis revealed that in the far-UV region (200 to $240 \mathrm{~nm}$ ), where the CD spectrum depends directly on protein conformation (Sparrow et al, 1992), the spectra of the carboxymethylated lactoferrin were different from those of the wild-type lactoferrin (Kao and Chung, 1993). As indicated in Figure $4 \mathrm{c}$, the longer incubation of carboxymethylated lactoferrin induced a progressively dynamic conformational change: $\beta$-sheet content increased and $\alpha$-helix content decreased in a time-dependent manner. The conformation of wild-type lactoferrin did not change during incubation. It is widely believed that precursor proteins of various types of amyloidosis tend to have abundant $\beta$-sheet structures (Sparrow et al, 1992; Sunde and Blake, 1997). However, a few proteins that do not have a rich $\beta$-sheet structure also form amyloid fibrils (Jonas et al, 1993). As demonstrated in this case, those proteins can proceed to amyloid formation if conformational change is induced.

Lactoferrin consists of a single polypeptide chain with a molecular size of $78.3 \mathrm{kDa}, 693$ amino acid residues, and limited glycosylation (Karthikeyan et al, 1999; Sharma and Singh, 1999a, 1999b). As in the other hereditary amyloidosis, it may be that mutant lactoferrin can form amyloid fibrils. It has been well documented that mutant amyloidogenic proteins show conformational changes, which increases amyloid formation ability (Benson and Uemichi, 1996; Kelly, 1998). The same may be true for the mutant lactoferrin. However, patients examined previously had neither family history nor corneal changes typical of those diseases (Klintworth et al, 1997), whereas one amino acid substitution in lactoferrin Glu561Asp was detected in all patients examined. It is possible to consider that the Glu561Asp mutation may be strongly related to the corneal amyloidosis. However, lactoferrin gene analysis for 38 healthy volunteers revealed that the frequency of genotype Ala/Thr +/+, Glu/Asp $+/+$, and Ala/Thr +/+ plus Glu/Asp +/+ was 34.2\%, $44.8 \%$, and $15.8 \%$, respectively (Table 2). Statistical analyses revealed no significance of the mutation on the corneal lactoferrin amyloidosis $(p=0.104)$, suggesting that the mutation of lactoferrin may not be an essential mutation for amyloid formation. However, there is a possibility that this mutation of lactoferrin Glu561Asp may be more susceptible to induce structural changes than wild-type lactoferrin during longlasting stimulation of the corneal surface by trichiasis.

In patients with lactoferrin amyloidosis, long-lasting stimulation of the corneal surface by trichiasis may alter the characteristics of the corneal surface and lactoferrin may remain on the cornea, which may lead to the structural changes of lactoferrin and thus to the formation of amyloid fibrils.

In summary, lactoferrin is produced in patients with corneal amyloidosis when trichiasis is an accompanying feature, and lactoferrin forms amyloid fibrils when conformational changes in lactoferrin occur. To confirm this hypothesis, we must examine more patients with corneal amyloidosis.

\section{Materials and Methods Patients}

Patients were a 30-year-old man and 41- and 67-yearold women who suffered from trichiasis with a corneal mass for 3, 7, and 10 years, respectively. Slit lamp examination showed all corneal masses as white excrescences. Neurologic examination and blood analysis indicated no signs of amyloidosis, and no amyloid deposition was found by Congo red staining of a biopsy specimen of the gastric and duodenal mucosae. After informed consent of the patients was obtained, masses were excised and examined by light and electron microscopy.

\section{Materials}

Lactoferrin and polyclonal anti-human lactoferrin antibody, anti-human SAP antibody and other antibodies tested were purchased from Sigma Chemical (St. Louis, Missouri) and Dako (Carpinteria, California), respectively. Chemicals used in histochemical and biochemical studies were of analytical grade.

\section{Congo Red Staining}

For all specimens, formalin-fixed, paraffin-embedded sections were stained with hematoxylin-eosin and Congo red and were examined under polarized light for the presence of green birefringence. 


\section{Immunohistochemical Analysis of Biopsy Specimens}

Specimens were fixed in $4 \%$ buffered paraformaldehyde. Paraffin-embedded biopsy samples were serial cut at $4 \mu \mathrm{m}$. For immunohistochemical demonstration of immunoreactivity for polyclonal anti-lactoferrin antibody in amyloid deposits, the avidin-biotin complex method was used (Dako, Glostrup, Denmark) according to the manufacture's instructions.

\section{Preparation of Tissues for Electron Microscopy}

Biopsied tissues were cut into small pieces of approximately $1 \mathrm{~mm}^{3}$ and were fixed with $3 \%$ glutaraldehyde in $0.1 \mathrm{M}$ phosphate buffer, $\mathrm{pH} 7.4$, for 2 hours at $4^{\circ} \mathrm{C}$. The pieces were postfixed with $2 \%$ osmium tetroxide in the same buffer for 2 hours at $4^{\circ} \mathrm{C}$. They were then dehydrated in graded alcohol and embedded in Epon. Ultra-thin sections 50 to $60 \mathrm{~nm}$ thick were stained with uranyl acetate and lead citrate and then were examined by use of the Hitachi 7000 electron microscope (Hitachi; Hitachi, Japan).

\section{Immunolabeling of Biopsied Samples}

Sections were collected on nickel grids coated with collodion. After grids were rinsed in $0.5 \%$ bovine serum albumin in PBS (100 mM, pH 7.4), they were transferred to a 1:500 dilution of anti-lactoferrin antibody (Dako, Carpinteria, California) for 24 hours at $4^{\circ} \mathrm{C}$. The grids were then rinsed in PBS for 30 minutes and placed on drops of a 1:100 solution of protein $A$ gold (5-nm gold particles) serum (British Biocell, Cardiff, United Kingdom). They were washed in PBS and stained with uranyl acetate and lead citrate and were analyzed by electron microscopy.

\section{Sample Preparation for Analyses of Amyloid Fibrils}

To extract amyloid fibrils in a biopsied sample from the 30-year-old man, the excised tissue was repeatedly (at least five times) homogenized in $0.15 \mathrm{M} \mathrm{NaCl}$ containing $0.05 \mathrm{M}$ sodium citrate and centrifuged (Haggqvist et al, 1999). After homogenization and centrifugation, the pellet was ultrasonicated (Branson 1200, Hartford, Connecticut) for 1 hour, after addition of $1 \%$ SDS, $150 \mathrm{~mm} \mathrm{NaCl}$, and $50 \mathrm{~mm}$ Tris- $\mathrm{HCl}, \mathrm{pH} 7.4$. Insoluble materials were collected by centrifugation at $50,000 \times g$ (RPV-50T, Hitachi, Hitachi, Japan). The resulting pellet was stirred vigorously in the same buffer, and the procedure was repeated three times. The resulting pellet was washed with distilled water, suspended in $1 \mathrm{ml}$ of distilled water, and centrifuged at $50,000 \times g$ for 30 minutes. The final pellet was transferred to a glass tube and was extracted with $10 \mathrm{ml}$ of 1,1,1,3,3,3,-hexafluoro-2-propanol (HFIP) for 30 minutes $\left(24^{\circ} \mathrm{C}\right)$ on a shaker. The HFIP extract was filtered through a $1,000-\mathrm{kDa}$ cutoff membrane (Pall Filtron, Northborough, Massachusetts) to remove coarse debris, and dried in a vacuum centrifuge. The obtained amyloid fibrils were ultrasonicated (Branson 1200) for 1 hour after addition of $20 \mu \mathrm{l}$ of $6 \mathrm{M}$ guanidinehydrochloride. After ultrasonication, $500 \mu \mathrm{l}$ of $50 \mathrm{~mm}$
Tris- $\mathrm{HCl}$ and $50 \mu \mathrm{l}$ of polyclonal anti-human lactoferrin antibody were added and incubated overnight (final concentration, $226 \mathrm{~mm}$ guanidine-hydrochloride). The resulting precipitate was centrifuged at $9,000 \times g$ for 5 minutes and washed two times with $100 \mu \mathrm{l}$ saline and $100 \mu \mathrm{l}$ water, respectively, at $4^{\circ} \mathrm{C}$. The precipitate was dissolved in $50 \mu \mathrm{l}$ of $4 \%$ acetic acid and $4 \%$ acetonitrile in water and the solution was passed through a $1,000-K D a$ centrifugal concentrator (Pall Filtron) to separate the dissociated lactoferrin from the antibody into the pass-through fraction.

\section{Electrophoresis after Immunoprecipitation}

The pass-through fraction was dissolved in $9 \mathrm{~m}$ urea $(100 \mu l)$, heated in a boiling-water bath for 5 minutes, and then mixed with $50 \mu \mathrm{l}$ of sample buffer consisting of $0.3 \mathrm{M} \mathrm{Tris}-\mathrm{HCl}$ at $\mathrm{pH} 8.6,30 \%(\mathrm{vol} / \mathrm{vol})$ glycerol, and $6 \%(\mathrm{wt} / \mathrm{vol}) 2$-mercaptoethanol, after which it was subjected to SDS-PAGE using gradient polyacrylamide gel containing $5 \%$ to $20 \%$ SDS (Daiichi Pure Chemicals, Tokyo, Japan) (Lukacova et al, 1994). The sample was electrotransferred and blotted onto PVDF membrane for 120 minutes. After this electrotransfer, the blots were stained with $0.1 \%$ Coomassie brilliant blue G-250 in 50\% methanol/10\% acetic acid and were destained with $50 \%$ methanol.

\section{N-Terminal Sequence Analysis}

$\mathrm{N}$-terminal sequence analysis was performed on the bands stained by Coomassie brilliant blue G-250 by use of a gas-phase protein sequencer (Hewlett Packard, Palo Älto, California).

\section{Amyloid Fibril Synthesis}

Denatured lactoferrin was produced from the pure commercial protein by incubation in $10 \mathrm{M}$ urea and $0.15 \mathrm{M}$ dithioerythritol for 2 hours at $20^{\circ} \mathrm{C}$. For carboxymethylation of the protein, the solution was treated with $0.4 \mathrm{~m}$ iodoacetic acid for 30 minutes at room temperature. The solution was then acidified to $\mathrm{pH} 3$ by addition of $1 \mathrm{~N} \mathrm{HCl}$, dialyzed extensively against $0.1 \mathrm{M}$ acetic acid at $4^{\circ} \mathrm{C}$, and then freezedried. The resulting protein was stored in nitrogen at $20^{\circ} \mathrm{C}$.

Carboxymethylated lactoferrin was solubilized by sonication in an appropriate aging solution (Kao and Chung, 1993). The solution was centrifuged at 9,000 $\times g$ at $4^{\circ} \mathrm{C}$ to remove insoluble debris, and the supernatant was collected for experiments on amyloid formation. The protein content was measured by the BCA protein assay reagent (Pierce Chemical, Rockford, Illinois) and the samples were stored at $-80^{\circ} \mathrm{C}$ until required. We analyzed lactoferrin by SDS-PAGE to confirm that this treatment resulted in no degradation of lactoferrin. Both wild-type lactoferrin and carboxymethylated lactoferrin were incubated in $50 \mathrm{~mm}$ $\mathrm{CH}_{3} \mathrm{COONa}, 100 \mathrm{~mm} \mathrm{KCl}, \mathrm{pH} 3.5$ to 7.0 , for examination of amyloid formation in vitro. 


\section{Electron Microscopic Analyses}

The sample containing synthesized lactoferrin filaments was centrifuged at $7,000 \times g$ for 5 minutes; pellets were then suspended in $1 \mathrm{ml}$ of distilled water. This process was repeated three times. A microdrop of the pellet resuspended in distilled water was placed on collodion-coated grids and was stained with $2 \%$ phophotungustic acid adjusted to $\mathrm{pH} 7.4$. The specimens were examined by use of a Hitachi H700O electron microscope (Hitachi) at an accelerating voltage of $100 \mathrm{kV}$.

\section{Dye Binding Studies}

Thioflavin $\mathrm{T}$ binding was measured with an emission fluorescence at $482 \mathrm{~nm}$ and with $450 \mathrm{~nm}$ as the excitation wavelength (LeVine, 1993).

\section{Measurements}

CD spectra were obtained with a Jasco J-720 spectropolarimeter fitted with a 150-watt xenon lamp. Quartz cells with a 1-mm path length were used, and spectra were recorded in the far-UV region (200 to 240 $\mathrm{nm}$ ) at a $5 \mathrm{~nm} /$ minute scanning speed and at room temperature. Three scans were averaged for each spectrum. The acquired spectra were corrected by subtracting the appropriate blank runs of PBS (-), pH 7.4 , subjected to noise reduction analysis and presented as the mean molar ellipticity, using 691 as the number of amino acid residues. The final protein concentration was $100 \mu \mathrm{g} / \mathrm{ml}$. Secondary structure fractions of native lactoferrin and carboxymethylated lactoferrin were estimated by use of the k2d program (Andrade et al, 1993; Merelo et al, 1994). This program determines the contributions of $\alpha$-helix, $\beta$-sheet, and random coil.

\section{SSCP Analysis}

In the 30-year-old man and his family, total genomic DNA was isolated from peripheral blood cells as described previously (Madisen et al, 1987). In the 41- and 67-year-old women, total genomic DNA was isolated from paraffin sections by using DEPAT kit (Takara, Shiga, Japan). SSCP analysis was performed according to the method of Orita et al (1989). The PCR primer sets used based on previous reports (Kim et al, 1998) were for exon 1: 5'-CCAGCCGAGTTTCTCAAGTC-3' and 5'CCCCAGGCACCTGCACTCAC-3'; exon 2: 5'-CCTTGGCCCCTCTCTCCCAG-3' and 5'-AACACCCGGCATTGACTCAC-3'; exon 3: 5'-TCTGGCCTCTTTACTITCAG$3^{\prime}$ and 5'-GGGTCCCCAGGCAGAACTAC-3'; exon 4: 5'-TTCTGTCTGCCCCTITGCAG-3' and 5'-TATGCCCCCAGCCATCTTAC-3'; exon 5: 5'-CACTTCTCTGTGTTAACAG-3' and 5'-AAGGGGACAGGGTCACTCAC-3'; exon 6: 5'-GATGGTTCTCTITCACAG-3' and 5'-GCTCATTACCCTGCTCTTAC-3'; exon 7: 5'-CCACCTCACCTTCCCTGCAG-3' and 5'-AAGTGGGGAGGACCGTGGGT-3'; exon 8: 5'-TCCCTATTTACCATTGACAC-3' and 5'-AAGTAGAAGACCACACCAGG-3'; exon 9: 5'-GCAAAGCTCAGGTTGCCCAG-3' and 5'-
ATGCCCAGGCCCTAGGTCTT-3'; exon 10: 5'-AGCCTCACTGTGGTGCTGGA-3' and 5'-ACTCCCATGACCCAGAGGGA-3'; exon 11: 5'-AGAGTTTGTGGCTTCTCACT-3' and 5'-CCAGCAACAAGAACTTATCC-3'; exon 12: 5'-CCTGGAGGTTAAGACTTGTT-3' and 5'-CCACAGCACAATATGCCTAC-3'; exon 13: 5'-TGGACTCAGGTTTGAAGAGC-3' and 5'-GCTGAGGGATGAGGTAAGTC-3'; exon 14: 5'-GAAAGCCCCACTAGTTTCTC-3' and 5'-CCAAAGACTCTGCTTTGAAG-3'; exon 15: 5'-CGTGGATGATGCCACCTTCT-3' and 5'-GCCCACACAGCTAAGAAAGC-3'; exon 16: 5'-CTTAGCTACTCACTGTCTGC-3' and 5'-CTTCACCCATGGTGGTTTCT-3'; exon 17: 5'-GTTTCTGAATCTCTTGCTCT-3' and 5'-AGAGCAGGGAATTGTAAGCA-3' (Kim et al, 1998) (GenBank Database accession no. U95626).

\section{Direct DNA Sequence Analysis}

The PCR products (5 ng) of exons 2, 9, 10, and 15 from the patient and the control subjects were analyzed, using 5' and 3' primers, by Thermo Sequenase radiolabeled terminator cycle sequencing kit (Amersham, Uppsala, Sweden).

\section{PCR-RFLP}

To confirm the mutation Ala11Thr, PCR was performed with the exon 2 primer set, and then PCR products were digested with ApaLI. To confirm the other mutation (Glu561Asp), we prepared the Glu561Asp PCR-RFLP primer (5'-GTCTGCCAGCTTCAAATCCTTAGCCCAGAC$\left.3^{\prime}\right)$, which annealed immediately $3^{\prime}$ to the mutation and contained mismatch bases (GA instead of a normal TG at the $2^{\prime}, 3^{\prime}$ position from the $3^{\prime}$ end) that created a unique Aatll restriction site, only when the lactoferrin gene had a $\mathrm{C}$ at position 3 of codon 561. After PCR amplification using the Glu561Asp PCR-RFLP primer and exon 15 outer primer (5'-GAAGCTCCTTCTCTGTTCCTCACA-3'), PCR products were digested with Aatll. After informed consent was obtained, 38 healthy Japanese volunteers were also examined in the same way to determine the frequency of these mutations. $\$$

\section{References}

Ando E, Ando Y, Okamura R, Ando M, and Negi A (1997a). Ocular manifestation of familial amyloidotic polyneuropathy type I: Long-term follow-up. Br J Ophthalmol 81:295-298.

Ando Y, Nyhlin N, Suhr O, Holmgren G, Uchida K, el Sahly M, Yamashita T, Terazaki H, Nakamura M, Uchino M, and Ando M (1997b). Oxidative stress is found in amyloid deposits in systemic amyloidosis. Biochem Biophys Res Commun 232: 497-502.

Andrade MA, Chacon P, Merelo JJ, and Moran F (1993). Evaluation of secondary structure of proteins from UV circular dichroism spectra using an unsupervised learning neural network. Protein Eng 6:383-390.

Aso K and Wakakura M (2000). Corneal amyloidosis complicated by trichiasis. Immunohistochemical identification of the amyloid light chain protein. Jpn J Ophthalmol 44:191.

Baker EN, Anderson BF, Baker HM, MacGillivray RT, Moore SA, Peterson NA, Shewry SC, and Tweedie JW(1998). Three- 
dimensional structure of lactoferrin. Implications for function, including comparisons with transferrin. Adv Exp Med Biol 443:1-14.

Benson MD (1995). Amyloidosis. In: Scriver CR, Beaudet AK, Sly WS, and Valle D, editors. The metabolic and molecular bases of inherited disease. New York: McGraw-Hill, 41594191.

Benson MD and Uemichi T (1996). Transthyretin amyloidosis. Amyloid. Int J Exp Clin Invest 3:44-56.

Campos EC, Melato M, Manconi R, and Antonutto G (1980). Pathology of ocular tissues in amyloidosis. Ophthalmologica 181:31-40.

Colon W, Lai Z, McCutchen SL, Miroy GJ, Strang C, and Kelly JW (1996). FAP mutations destabilize transthyretin facilitating conformational changes required for amyloid formation. Ciba Found Symp 199:228-238.

Dutt S, Elner VM, Soong HK, Meyer RF, and Sugar A (1992). Secondary localized amyloidosis in interstitial keratitis. Clinicopathologic findings. Ophthalmology 99:817-823.

El-Salhy M and Suhr O (1996). Endocrine cells in rectal biopsies from patients with familial amyloidotic polyneuropathy. Scand J Gastroenterol 31:68-73.

Goldsteins G, Persson H, Andersson K, Olofsson A, Dacklin I, Edvinsson A, Saraiva MJ, and Lundgren E (1999). Exposure of cryptic epitopes on transthyretin only in amyloid and in amyloidogenic mutants. Proc Natl Acad Sci USA 96:31083113.

Gorevic PD, Munoz PC, Gorgone G, Purcell JJ, Rodrigues M, Ghiso J, Levy E, Haltia M, and Frangione B (1991). Amyloidosis due to a mutation of the gelsolin gene in an American family with lattice corneal dystrophy type II. N Engl J Med 325:1780-1785.

Haggqvist B, Naslund J, Sletten K, Westermark GT, Mucchiano G, Tjernberg LO, Nordstedt C, Engstrom U, and Westermark P (1999). Medin: An integral fragment of aortic smooth muscle cell-produced lactadherin forms the most common human amyloid. Proc Natl Acad Sci USA 96:86698674.

Hill JC, Maske R, and Bowen RM (1990). Secondary localized amyloidosis of the cornea associated with tertiary syphilis. Cornea 9:98-101.

Janssen S, Elema JD, van Rijswijk MH, Limburg PC, Meijer S, and Mandema E (1985). Classification of amyloidosis: Immunohistochemistry versus the potassium permanganate method in differentiating $A A$ from $A L$ amyloidosis. Appl Pathol 3:29-38.

Jonas A, von Eckardstein A, Churgay L, Mantulin WW, and Assmann G (1993). Structural and functional properties of natural and chemical variants of apolipoprotein A-I. Biochim Biophys Acta 1166:202-210.

Kao MC and Chung MC (1993). Pyridylethylation of cysteine residues in proteins. Anal Biochem 215:82-85.

Karthikeyan S, Paramasivam M, Yadav S, Srinivasan A, and Singh TP (1999). Structure of buffalo lactoferrin at 2.5 resolution using crystals grown at $303 \mathrm{~K}$ shows different orientations of the $\mathrm{N}$ and $\mathrm{C}$ lobes. Acta Crystallogr D Biol Crystallogr 55:1805-1813.

Kelly JW (1998). The alternative conformations of amyloidogenic proteins and their multi-step assembly pathways. Curr Opin Struct Biol 8:101-106.
Kigasawa K, Mashima Y, Ogata T, and Tashiro Y (1996). A histopathological study of corneal amyloidosis secondary to trichiasis. Nippon Ganka Gakkai Zasshi 100:394-400.

Kim SJ, Yu DY, Pak KW, Jeong S, Kim SW, and Lee KK (1998). Structure of the human lactoferrin gene and its chromosomal localization. Mol Cells 8:663-668.

Klintworth GK, Valnickova Z, Kielar RA, Baratz KH, Campbell RJ, and Enghild JJ (1997). Familial subepithelial corneal amyloidosis-a lactoferrin-related amyloidosis. Invest Ophthalmol Vis Sci 38:2756-2763.

Lee HM, Naor J, DeAngelis D, and Rootman DS (2000). Primary localized conjunctival amyloidosis presenting with recurrence of subconjunctival hemorrhage. Am J Ophthalmol 129:245-247.

LeVine H III (1993). Thioflavine T interaction with synthetic Alzheimer's disease $\beta$-amyloid peptides: Detection of amyloid aggregation in solution. Protein Sci 2:404-410.

Lukacova M, Kazar J, and Gajdosova E (1994). Coxiella burnetii phase I and II proteins studied by SDS-page. Acta Virol 38:263-267.

Madisen L, Hoar DI, Holroyd CD, Crisp M, and Hodes ME (1987). DNA banking: The effects of storage of blood and isolated DNA on the integrity of DNA. Am J Med Genet 27:379-390.

Merelo JJ, Andrade MA, Prieto A, and Moran F (1994). Proteinotropic feature maps. Neurocomputing 6:443-454.

Miyata T, Hori O, Zhang J, Yan SD, Ferran L, lida Y, and Schmidt AM (1996). The receptor for advanced glycation end products (RAGE) is a central mediator of the interaction of AGE-beta2 microglobulin with human mononuclear phagocytes via an oxidant-sensitive pathway: Implications for the pathogenesis of dialysis-related amyloidosis. J Clin Invest 98:1088-1094.

Nelson GA, Edward DP, and Wilensky JT (1999). Ocular amyloidosis and secondary glaucoma. Ophthalmology 106: 1363-1366.

Nishida K, Quantock AJ, Dota A, Choi-Miura NH, and Kinoshita S (1999). Apolipoproteins J and E co-localize with amyloid in gelatinous drop-like and lattice type I corneal dystrophies. Br J Ophthalmol 83:1178-1182.

Orita M, Suzuki Y, Sekiya T, and Hayashi K (1989). Rapid and sensitive detection of point mutations and DNA polymorphisms using the polymerase chain reaction. Genomics 5:874-879.

Pepys MB, Rademacher TW, Amatayakul-Chantler S, Williams P, Noble GE, Hutchinson WL, Hawkins PN, Nelson SR, Gallimore JR, Herbert J, Hutton T, and Dwek RA (1994). Human serum amyloid $\mathrm{P}$ component is an invariant constituent of amyloid deposits and has a uniquely homogeneous glycostructure. Proc Natl Acad Sci USA 91:5602-5606.

Quintas A, Saraiva MJ, and Brito RM (1997). The amyloidogenic potential of transthyretin variants correlates with their tendency to aggregate in solution. FEBS Lett 418:297-300.

Ratnakar KS and Mohan M (1976). Amyloidosis of the iris. Can J Ophthalmol 11:256-257.

Rodrigues M and Zimmerman LE (1971). Secondary amyloidosis in ocular leprosy. Arch Ophthalmol 85:277-279.

Sandgren O (1995). Ocular amyloidosis, with special reference to the hereditary forms with vitreous involvement. Surv Ophthalmol 40:173-196. 
Serpell LC, Sunde M, and Blake CC (1997). The molecular basis of amyloidosis. Cell Mol Life Sci 53:871-887.

Sharma AK and Singh TP (1999a). Structure of oxalatesubstituted diferric mare lactoferrin at 2.7 resolution. Acta Crystallogr D Biol Crystallogr 55:1792-1798.

Sharma AK and Singh TP (1999b). Lactoferrin-metal interactions: First crystal structure of a complex of lactoferrin with a lanthanide ion $\left(\mathrm{Sm}^{3+}\right)$ at 3.4 resolution. Acta Crystallogr D Biol Crystallogr 55:1799-1804.

Sparrow DA, Lee BR, Laplaud PM, Auboiron S, Bauchart D, Chapman MJ, Gotto AM, Yang CY, and Sparrow JT (1992). Plasma lipid transport in the preruminant calf, Bos spp: Primary structure of bovine apolipoprotein A-I. Biochim Biophys Acta 1123:145-150.

Sunde $M$ and Blake C (1997). The structure of amyloid fibrils by electron microscopy and X-ray diffraction. Adv Protein Chem 50:123-159.
Tan SY and Pepys MB (1994). Amyloidosis. Histopathology 25:403-414.

Tennent GA, Lovat LB, and Pepys MB (1995). Serum amyloid $\mathrm{P}$ component prevents proteolysis of the amyloid fibrils of Alzheimer disease and systemic amyloidosis. Proc Natl Acad Sci USA 92:4299-4303.

Tsujikawa M, Kurahashi H, Tanaka T, Nishida K, Shimomura Y, Tano Y, and Nakamura Y (1999). Identification of the gene responsible for gelatinous drop-like corneal dystrophy. Nat Genet 21:420-423.

Watts $\mathrm{J}$ and Frank $\mathrm{H}$ (1989). Corneal amyloidosis. $\mathrm{Br} \mathrm{J}$ Ophthalmol 73:674-676.

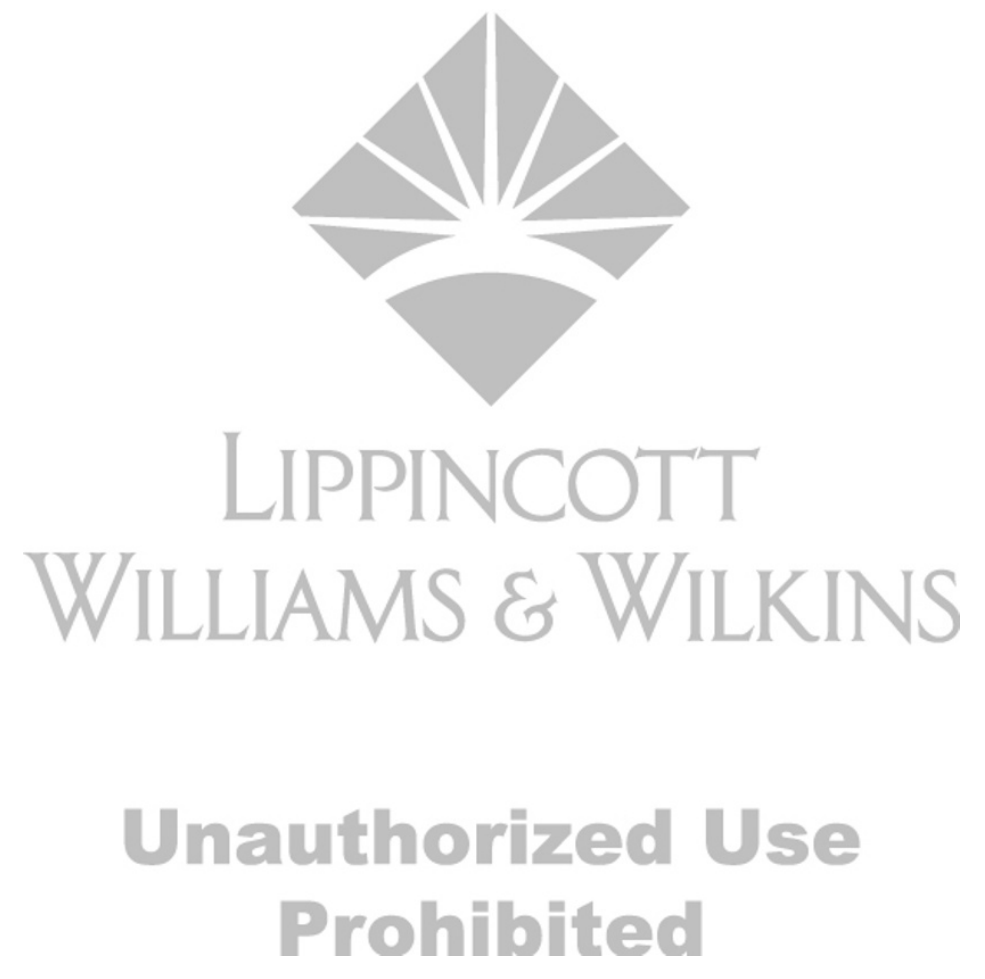

